University at Albany, State University of New York

Scholars Archive

$10-2016$

\title{
Advising a Model United Nations club: A scaffolded youth-adult partnership to foster active participation and political engagement
}

\author{
Brett Levy \\ University at Albany, State University of New York, bllevy@albany.edu
}

Follow this and additional works at: https://scholarsarchive.library.albany.edu/etap_fac_scholar

\section{Recommended Citation \\ Levy, Brett, "Advising a Model United Nations club: A scaffolded youth-adult partnership to foster active participation and political engagement" (2016). Educational Theory and Practice Faculty Scholarship. 14. https://scholarsarchive.library.albany.edu/etap_fac_scholar/14}

This Article is brought to you for free and open access by the Educational Theory and Practice at Scholars Archive. It has been accepted for inclusion in Educational Theory and Practice Faculty Scholarship by an authorized administrator of Scholars Archive. For more information, please contact scholarsarchive@albany.edu. 


\title{
Advising a Model United Nations Club: A Scaffolded Youth-Adult Partnership \\ to Foster Active Participation and Political Engagement
}

\author{
Brett L. M. Levy \\ University at Albany, State University of New York
}

Acknowledgements:

I would like to thank the University of Michigan's Rackham Graduate School for providing funding to support the research described in this paper. In addition, I appreciate the helpful feedback of colleagues who reviewed earlier drafts of this paper, including Carol Rodgers, Jacquelynne Eccles, Annemarie Palincsar, Michaela Zint, Richard Niemi, Erica Halverson, Melissa Braaten, and Brian Christens. Finally, I extend my deepest thanks to the educators and students who participated in this study and openly shared their perspectives and experiences. 


\begin{abstract}
Model United Nations is one of the world's most popular civic education programs, but there has been little research on how adult advisors of such programs support students' participation and political engagement. This study begins to address this research gap through a case study of one Model UN club. By analyzing data from over 150 hours of observation and from interviews with advisors and students, the author found that advisors facilitated the club as a scaffolded youthadult partnership and provided three major types of support: intellectual, administrative, and personal. Findings have implications for various extracurricular and classroom-based educational programs.
\end{abstract}

Keywords: civic engagement, civic education, extracurricular, out-of-school time, secondary students, adolescents, curriculum and instruction, social learning, youth leadership, developmental relationships, coaching

\title{
Article Highlights
}

- Advisors provided students with intellectual, administrative, and personal support.

- Over time, advisors shifted many responsibilities to skilled student members.

- Advisors and students co-designed many club activities and conference strategies.

- The club exemplified a youth-adult partnership with developmental relationships. 
"Democracy has to be born anew with each generation, and education is its midwife."

- John Dewey, School and Society

In many democratic countries around the world, citizens' involvement in political activities, such as voting and protesting, has fluctuated widely over time (Franklin, 2004; Pintor, Gratschew, \& Sullivan, 2001; Putnam, 2000), and young people tend to vote less than their older counterparts (Bouza, 2014; Center for Information and Research on Civic Learning and Engagement, 2013). Policymakers have undertaken various efforts to support political engagement among youth, including mandatory coursework on government, but these efforts have had mixed results (Niemi \& Junn, 1998; Gimpel, Lay, \& Schuknecht, 2003).

Prior research indicates that when young people are involved in interactive political experiences, such as political simulations and discussions, they are more likely to become politically engaged (review to follow), and scholars have begun to closely analyze how teachers manage political discussions (e.g., Hess, 2009; Parker \& Hess, 2001). However, there have been few studies examining how educators manage students' participation in complex political simulations. The study described in this paper begins to address this research gap by exploring advisors' practices in one high school's Model United Nations club. Model UN, a program in which students have opportunities to learn about diplomacy and international relations (National Model United Nations, 2016; United Nations Association of the USA, 2013), is one of the world's most popular extracurricular programs with about 400,000 participants from around the world each year (Williams, 2009), but little research has examined adult advisors' roles and strategies. By analyzing the pedagogical processes and mechanisms that support students' participation and political engagement, this paper makes an important contribution to the literature on educating for youth political engagement. 


\section{Political Simulations and Model UN}

Originating in the 1940s, the Model United Nations program includes a loose network of independent student clubs that participate in interscholastic conferences organized by local, regional, national, and international organizations. Although the first conferences were held in the United States, they now occur regularly in numerous countries, including Australia, China, Germany, India, Lebanon, Peru, and South Africa. Conferences are organized at the middle school, high school, and college levels (occasionally with students from various levels) and can include anywhere from a few dozen to several thousand students. During these events, students represent the policies of their pre-assigned countries in debates about a range of international challenges, such as nuclear proliferation, border conflicts, trade disputes, and natural disasters. These experiences provide young people with opportunities to learn about international issues and political negotiation through a variety of interactive experiences.

The specific formats of these large gatherings vary, but most conferences divide students into committees for the majority of the experience. To prepare, students are expected to conduct research that will enable them to appropriately represent their assigned countries' positions on the topics their committees will address. Then during committee meetings, students strive to design and pass (by majority vote) resolutions aimed at addressing the challenges under discussion in their committees (see Appendix A). At least one adult advisor must accompany each team, and at conferences their involvement is limited to supervision and support.

Although historically Model UN programs have been most prevalent in middle-class and affluent areas, over the past dozen years there has been a concerted effort to make Model UN available to a broader range of young people. With the goal of reaching traditionally underserved communities, the UN Association of the USA has launched the Global Classrooms program, 
which has supported Model UN programs and related classroom curricula in urban schools around the world (United Nations Association of the USA, 2009), including New Delhi, Beijing, Johannesburg, and Los Angeles. In the US, more than half the students attending conferences sponsored by the UNA-USA are from high-poverty Title I schools (T. Wolfe, personal communication, Feb. 12, 2013). Although UNA-USA conferences represent a minority of the overall Model UN gatherings, their inclusiveness nonetheless signifies the expanding diversity of Model UN participants.

Prior research on classroom-based political simulations suggests that students' experiences in Model UN can support their political efficacy and political interest, attitudes that political scientists have found to be reliable predictors of political participation (e.g., Brady, Verba, \& Schlozman, 1995; Leighley \& Vedlitz, 1999). ${ }^{1}$ For example, Dressner's (1990) examination of students participating in a simulation of a town hall conservation effort concluded that the activity supported students' political efficacy. Likewise, numerous other studies have found that participating in simulations in government classes can support young people's development of political efficacy (e.g., Bernstein, 2008; Boocock, 1968; Vogel, 1973) and political interest (e.g., Ganzler, 2010; McAvoy \& Hess, 2013).

Meanwhile, in a retrospective study, Patterson (1996) found that students who had participated in Model UN several years earlier attributed their political engagement to their experiences in these simulations. This and other research, led the Campaign for the Civic Mission of Schools $(2003,2011)$ to identify simulations as one of six "best practices" for fostering civic engagement. More recently, my research (20xx; 20xx; under review) indicates

${ }^{1}$ Political efficacy is commonly defined as "the feeling that political and social change is possible and that the individual citizen can play a part in bringing about this change" (Campbell, Gurin, \& Miller, 1954), and political interest is conceptualized as "citizens' willingness to pay attention to politics at the expense of other endeavors" (Lupia \& Philpot, 2005). 
that participating in Model UN activities with advisors' guidance and scaffolding can support adolescents' political interest and efficacy. These earlier analyses considered the experiences and outcomes of 36 student participants in the club whose advisors are explored in this paper. ${ }^{2}$

Despite the growing popularity of Model UN and the educational potential of such political simulations, no published research has closely examined how adult advisors support students' participation. This study fills an important gap in the research literature by contributing to our understanding of how advisors can structure the Model UN experience to strengthen students' participation and increased political engagement. Findings have implications for not only leaders of Model UN programs around the world but also for advisors and facilitators of other educational programs in which youth and adults work closely together over time.

\section{Conceptual Framework}

Like many learning experiences that require creative problem-solving, Model UN programs often involve collaborative interactions among young people and adult advisors. The tasks of building a school club and developing sophisticated, targeted political arguments can benefit tremendously from integrating diverse perspectives. In an educational environment where one's students may be widely dispersed, each pursuing different but inter-related sub-goals, providing relevant guidance requires careful listening and customized feedback.

Thus, this study builds on previous research that analyzes and identifies the mechanisms involved in educational collaborations with both youth and adults. Educators in New Zealand and elsewhere are increasingly encouraged to learn collaboratively with youth rather than foster

\footnotetext{
${ }^{2}$ Drawing on survey data at the beginning and end of a six-month period, I found that students who participated in this Model UN club were more likely than a demographically similar comparison group to develop greater political efficacy and political interest, controlling for age, grade, GPA, and parental education levels. Survey items were adapted from the American National Election Study (Craig, Niemi, \& Silver, 1990) and studies of the expectancyvalue model (Eccles, 2005). Data from numerous student interviews and observations of club activities supported these findings and indicated that advisors played a central role in supporting and scaffolding students' increasing depth of participation over their time in the club (Levy, 2011a).
} 
unidirectional learning from teacher to student (Sewell, St. George, \& Cullen, 2013). Recent research suggests that these experiences can be most successful when they include developmental relationships (Li \& Julian, 2012) within structured youth-adult partnerships (Zeldin, Christens, \& Powers, 2013). Ultimately, these contexts can provide unique opportunities for youth to practice the skills that support their increased organizational participation and political engagement.

Li and Julian (2012) found that developmental relationships are central for positive youth development and empowerment. These relationships enable adults to support youth learning first by providing deliberate guidance and scaffolding and then by gradually removing this support. Throughout the process, decision-making and learning are bi-directional, with adults listening and attending to the needs and interests of the youth rather than dictating content and activities for them. There are four key aspects of developmental relationships: attachment, reciprocity, progressive complexity, and balance of power. Li and Julian found that when these elements are present, human development is more positive, as evidenced in a variety of programs, including an elementary school, orphanage, and big brother/big sister program. Other scholars (e.g., Yohalem \& Wilson-Ahlstrom, 2010) have also found these elements, especially attachment and emotional support, to be particularly important for a variety of positive youth outcomes, such as learning and school adjustment.

One context in which these relationships can develop is youth-adult partnerships (Y-AP). Zeldin, Christens, and Powers (2013) define Y-AP as the practice of “(a) multiple youth and multiple adults deliberating and acting together, (b) in a collective [democratic] fashion (c) over a sustained period of time, (d) through shared work, (e) intended to promote social justice, strengthen an organization and/or 
affirmatively address a community issue" (p. 4, 6).

They identify four key attributes of effective Y-APs, which overlap somewhat with the aforementioned characteristics of developmental relationships: natural mentors, reciprocal activity, authentic decision-making, and community connectedness.

A large body of research documents the benefits of each of these program attributes. For example, when youth participate in authentic group decision-making, they are more likely to develop skills, mastery, confidence, and emotional well-being (e.g., Dworkin, Larsen, \& Hansen, 2003; Mitra, 2004). Likewise, research syntheses have found that youth empowerment develops when young people believe that they have made meaningful contributions to others and when the balance of power gradually shifts from adults towards youth (Benson, Scales, Hamilton, \& Sesma, 2006; Hamilton \& Hamilton, 2009; Wong, Zimmerman, \& Parker, 2010). One research review found that building strong, interactive communities of learners can even support knowledge application, retention, and transfer (Watkins, 2005). Other scholars have emphasized the educational potential of carefully sequenced programs (Durlak, Weissberg, \& Pachan, 2010; Yohalem \& Wilson-Ahlstrom, 2010), purposeful engagement for youth (Smith, Peck, Denault, Blazevski, \& Akiva, 2010), and attentive adult guidance during young people's explorations (Rogoff, Turkanis, \& Bartlett, 2001; Rogoff, 2003), all of which can be accomplished within well-designed Y-APs.

As Kirshner (2008) found, youth and adults can work productively together towards meaningful civic goals in various structural arrangements, some of which are more youthcentered than others. In a comparison of community programs, he identified three types of youthadult cooperation. Whereas “joint work" involved stronger adult participation in a group's activities, an "apprenticeship" arrangement included a careful balance between youth and adults, 
with youth more involved in significant decisions. In an even more youth-centered environment, adults primarily provided "facilitation," and young people led meetings and made many major decisions. While the programs in Kirshner's study each had a dominant structural arrangement, he observed all three interactional patterns in each program. These findings suggest ways that youth-adult partnerships could progressively foster developmental relationships, with the balance of power shifting from adults to youth as young people develop greater competence on key tasks. In addition to supporting youth learning and positive emotional development, such youthadult organizations could provide an ideal context in which youth can openly participate in many of the activities known to support political interest and efficacy. For example, research suggests that political efficacy increases when individuals have opportunities to participate in democratic processes (Ikeda, Kobayashi, \& Hoshimoto, 2008; Finkel, 1985; Siegel, 1977) and feel connected to communities (Steinberger, 1981) or powerful social groups (Koch, 1993; Louis, Taylor, \& Neil, 2004). In addition, discussing controversial public issues in an open climate can have a positive effect on both political self-efficacy (Morrell, 2005; Hahn, 1999) and political interest (Hahn, 1999; Kahne, Crow, \& Lee, 2010).

The structure of Model UN provides an opportunity to build organizations that facilitate these experiences within the context of a youth-adult partnership that fosters developmental relationships. In this study, I examined how and the extent to which advisors in one Model UN club in the Midwestern United States created an environment in which youth became increasingly involved in their club's activities in ways that supported their greater political interest and efficacy (see Levy, 2011a, for details of youth political engagement findings). 


\section{Aims and Methods}

The overall purpose of this study was to explore, identify, and analyze the specific ways that advisors of Model UN clubs could help students to become productively engaged in their groups' activities and increasingly engaged in political issues. To explore this, I conducted a case study of a reputable extracurricular Model UN program whose delegates had garnered numerous awards over the club's history. The specific research question guiding this study was: How do advisors in one extracurricular Model UN club facilitate student members' active club participation and increased political engagement?

\subsection{Case Study}

To address this research question, I conducted a case study of the Model UN club at Elmwood High School (all names of institutions and individuals are pseudonyms), a middleclass semi-urban area bordering a major Midwestern city. Conducting a case study can be a useful method for identifying nuances within new areas of inquiry (Foreman, 1948; Merriam, 1988; Stake, 1995). Whereas prior studies had documented activity structures during Model UN (e.g., Hazleton \& Jacob, 1983; Patterson, 1996; Turner, 1997), this study is the first to examine the specific elements of advisors' roles.

The present study was part of a larger mixed methods examination of Elmwood High School's civic engagement activities (Levy, 2011a, 2011b, 2013). As noted above, findings from this broader study indicated that students' involvement in Elmwood's Model UN club supported their increased political efficacy and interest. Their participation had many dimensions, but one consistent force throughout their experiences was advisors' support. 


\subsection{Context of the Study: Elmwood High School Model UN}

To explore advisors' strategies for supporting students' Model UN participation and political engagement, I closely examined Elmwood's Model UN program during the 2009-10 academic year. The club had been established in 1995 through the efforts of a handful of students and one faculty advisor and had grown to have three advisors and up to sixty students per year.

Elmwood High School overall had approximately 1,650 predominantly middle class students, and the Model UN club reflected the demographics of the school, which was 90 percent white, two percent African-American, two percent Asian-American, three percent Latino, and three percent other. Despite its limited diversity, I selected this site because of its unique reputation for broad student involvement and strong performance.

\subsection{Data Collection}

For this study, I collected data over the course of nine months by interviewing teachers and students and recording field notes of observations of club and conference activities. ${ }^{3} \mathrm{I}$ gathered these data between mid-August, 2009 and mid-May, 2010, and during this time, Elmwood's Model UN club prepared for and attended three interscholastic conferences, each managed by different groups - one by high school students, one by college students, and the third by an independent non-profit organization (See Table 1).

Table 1

Characteristics of Three Conferences Attended by Elmwood High School Model UN during Study Period

\begin{tabular}{|l|l|c|c|c|c|c|}
\hline $\begin{array}{c}\text { Conference } \\
\text { Location }\end{array}$ & \multicolumn{1}{|c|}{ Date } & $\begin{array}{c}\text { Total } \\
\text { Days }\end{array}$ & $\begin{array}{c}\text { Elmwood } \\
\text { Participants }\end{array}$ & $\begin{array}{c}\text { Elmwood } \\
\text { Countries }\end{array}$ & $\begin{array}{c}\text { Conference } \\
\text { Committees }\end{array}$ & $\begin{array}{c}\text { Approximate Total } \\
\text { Delegates }\end{array}$ \\
\hline High School & Oct., 2009 & 1 & 30 & 10 & 11 & 190 \\
\hline Large Hotel & Nov., 2009 & 3.5 & 21 & 6 & 7 & 250 \\
\hline University & Jan., 2010 & 3.5 & 35 & 7 & 11 & 400 \\
\hline
\end{tabular}

\footnotetext{
${ }^{3}$ This study was approved by the Institutional Review Board at [my university], and I complied with the ethical and legal frameworks outlined by the American Psychological Association and relevant state authorities. All participants were appropriately informed of their rights as research participants.
} 
To examine advisors' practices and students' participation, I conducted observations and interviews of students and teachers throughout the study period. Specifically, I observed students' weekly membership meetings each Monday and officer meetings each Friday, keeping systematic field notes and audio recordings of each observation. In addition, I attended the club strategy meetings in August and March as well as all three interscholastic conferences, during which I visited each committee meeting room one or more times. In total, I observed over 150 hours of Model UN activities. My field notes recorded advisors' facilitation strategies, student interactions with advisors and one another, and the amount of time dedicated to various activities.

Each advisor was interviewed at least twice during the study period. These semistructured interviews (Merton, Fiske, \& Kendall, 1990) each lasted between twenty and forty minutes and included questions related to advisors' goals, experiences, challenges, and perceptions of their own roles. For example, I asked each advisor, "When you think about your work advising Model UN, what would you say are your main goals for students?" and "What have been some of your most memorable and/or challenging experiences as an advisor?” I conducted numerous shorter interviews with the main advisor, Mr. Kendall, to learn about events that I was unable to observe and his perspective on students' experiences (see section 4.1 below for details about advisors). Furthermore, I interviewed numerous students $(\mathrm{N}=25)$ about their experiences in the club, including the roles of their advisors.

\subsection{Data Analysis}

To analyze data from interview transcripts and observation field notes, I used the constant comparative method (Glaser \& Strauss, 1967; Corbin \& Strauss, 1999). Beginning in September, I conducted open coding of these data, and then throughout the study, I repeatedly revised, combined, and reorganized these codes. Major codes related to advisors' facilitation strategies 
were: (1) administrative support, (2) intellectual support, and (3) personal support. While specifying subcategories within these codes, I wrote analytic memos regularly to explore coding dimensions and relationships among them. After I finished collecting data, I continued to narrow my coding scheme, analyze relationships among codes, record analytic memos, and develop theory about the ways in which Elmwood's Model UN club exemplified, challenged, or extended theories about youth-adult partnerships and developmental relationships.

\section{Findings}

Elmwood's Model UN club was an extremely active organization, with advisors fostering students' participation and political engagement via intellectual, administrative, and personal support. In various activities, youth and adults worked reciprocally as partners, with decisionmaking responsibility shifting towards the youth as they demonstrated their increasing competence. Thus, advisors positioned their interactions with students alternately as joint work, apprenticeship, and facilitation - though they made clear that their goal was for students to take the lead and become engaged in both the club and the broader political sphere. Below, I present detailed findings about the types of support and mentoring that advisors provided as students became increasingly involved in their Model UN club and engaged in political issues.

\subsection{Overview of Club Activities and Advisors' Roles}

When this study began, Elmwood Model UN had existed for over twelve years, with two advisors who had collaborated to lead the club for most of that time and a third advisor who joined the club primarily for conferences. The club's tradition was to offer its members opportunities to participate in up to four conferences per year, and usually between 20 and 35 would attend each. To prepare for conferences, students raised money to pay for club members' conference expenses (e.g., registration fees) and participated in club-based conference 
preparation activities. Through weekly club meetings as well as weekly officers' meetings throughout the academic year, the group organized activities and interactions that facilitated students' active participation in conference activities. Advisors were present for many of these (see Table 2) and as I detail below, spent this time in various roles, sometimes providing direct guidance or scaffolding and at other times simply observing.

Table 2

Advisors' Presence at Elmwood High School's Model UN Club Activities

\begin{tabular}{|l|l|l|l|}
\hline Activity & Duration & Frequency & Advisors Present \\
\hline Interscholastic Conferences & $1-4$ days & 4 per year & Usually all 3 \\
\hline $\begin{array}{l}\text { Conference Prep Meetings } \\
\text { (small groups) }\end{array}$ & $1-2$ hours & $\begin{array}{l}\text { Usually 2-4 } \\
\text { times/conference }\end{array}$ & One or None \\
\hline Full Club Meetings & 1 hour & Weekly (“MUNdays") & Kendall \& Stein \\
\hline Officers' Meetings & 1 hour & Weekly (Fridays) & Kendall \\
\hline Fundraisers & $1-5$ days & 5 per year & One or None \\
\hline Strategic Planning Meetings & $4-6$ hours & 2 per year & Kendall \\
\hline $\begin{array}{l}\text { Educational Events (for non- } \\
\text { members) }\end{array}$ & $1-6$ hours & $2-4$ per year & Stein \\
\hline
\end{tabular}

After students signed up for a conference, they received their country and committee assignments (based on combined preferences of the organizers, advisors, and students) and then began conference preparation, which typically included conducting research and writing a "position paper" to clarify their countries' stances on their committees' issues (See Table 3 and Appendix B). These occurred through meeting with an advisor (individually or with peers), independent work, and/or country delegation meetings, and then at conferences, students were expected to attend their committees' sessions in the morning, afternoon, and evening (see Appendix C). In their committees, students used parliamentary procedure to explore the preassigned topics and surprise "crises" (see Appendix D) - making speeches, holding caucuses, discussing debate procedures, and designing resolutions to address the major issues under discussion. They had numerous opportunities to work with others, form alliances, discuss substantive political issues, vote on specific measures, and lobby others for their votes (see 
Figure 1). Thus, participating in Model UN involved some intellectually demanding tasks, and students required varying amounts of support to engage in these.

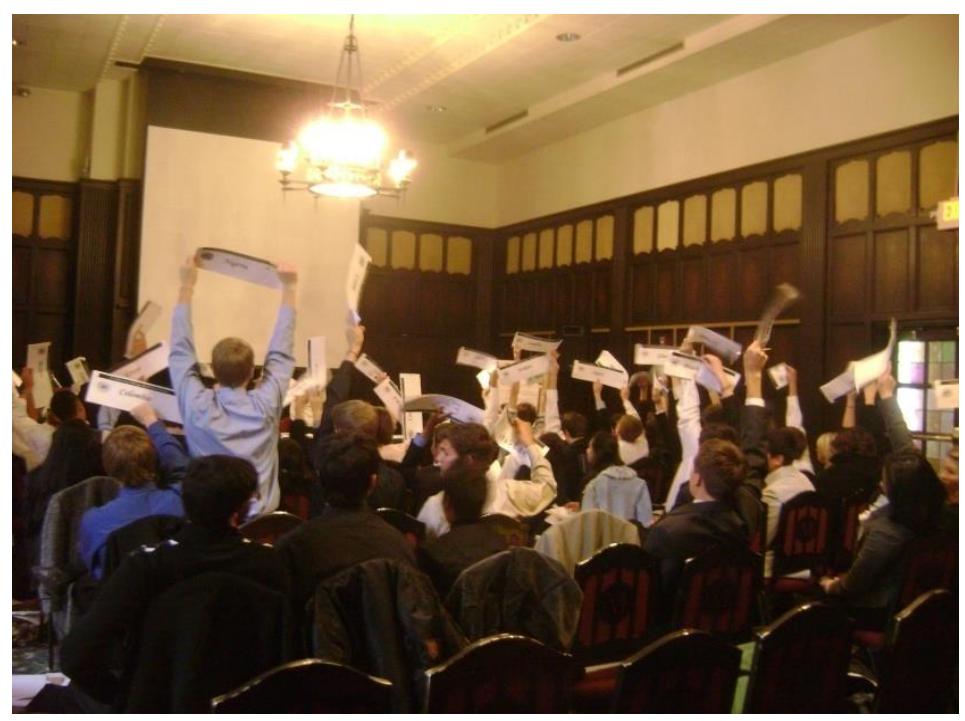

Figure 1. Model UN students voting on an amendment to a resolution

Table 3

Committees and Debate Topics at a Model UN Conference attended by Elmwood Students

\begin{tabular}{|c|c|}
\hline Committee & Debate Topics \\
\hline \multirow{3}{*}{ Human Rights Council } & Freedom of the Press \\
\hline & Rights of Lesbian and Gay \\
\hline & Individuals \\
\hline \multirow{2}{*}{ Social and Economic Committee } & International Labor Standards \\
\hline & Indigenous Land Rights \\
\hline \multirow{2}{*}{ World Health Organization } & Pandemic Flu \\
\hline & Access to Safe Drinking Water \\
\hline \multirow{2}{*}{ Security Council } & Afghanistan’s Instability \\
\hline & Iran's Nuclear Program \\
\hline \multirow[t]{2}{*}{ Political Committee } & Illicit Trade in Small Arms \\
\hline & Electoral Violence and Intimidation \\
\hline \multirow[t]{2}{*}{ Special Political Committee } & Situation in Korean Peninsula \\
\hline & Israeli-Palestinian Conflict \\
\hline Social, Cultural, and Humanitarian & Children in Armed Conflict \\
\hline Committee & Eliminating Racism \\
\hline
\end{tabular}

Throughout conferences and conference preparation experiences, the club's advisors emphasized the value of these tasks, provided tips, and made themselves available, but they 
directed students only when they considered it absolutely necessary, instead encouraging them to make autonomous choices in their strategies and degrees of effort (details below). They spent a substantial portion of conferences sitting in the back of committee rooms, observing students' progress, and offering occasional words of support or advice. Between conferences they helped to facilitate students' content learning and club governance (see Table 4). Indeed, among the advisors' main goals were to build students' leadership skills and potential, as Mr. Stein explained:

It can be very tangible watching a student who is a freshmen or sophomore or a new upperclassman who's not very outspoken - watching that student become a leader by the time he or she is a senior. It's pretty rewarding as an educator to see that sort of growth (Interview, November 18, 2009).

In the summary of my analyses below, I describe how advisors supported students' participation in and stewardship of various aspects of the club.

Table 4

Characteristics of Model UN Advisors

\begin{tabular}{|l|c|c|l|l|}
\hline Advisor & Age & $\begin{array}{c}\text { Years } \\
\text { Advising }\end{array}$ & Main Goals for Students & Involvement in Model UN \\
\hline $\begin{array}{l}\text { Sam Kendall, } \\
\text { English Teacher }\end{array}$ & 46 & 15 & $\begin{array}{l}\text { Empowerment } \\
\text { Leadership Opportunities }\end{array}$ & $\begin{array}{l}\text { Weekly Full Club Meetings } \\
\text { Weekly Officers' Meetings } \\
\text { All Conferences (four/year) } \\
\text { Pre-conference Delegation Meetings } \\
\text { Fundraisers (occasionally) }\end{array}$ \\
\hline $\begin{array}{l}\text { Evan Stein, } \\
\text { History Teacher }\end{array}$ & 37 & 12 & $\begin{array}{l}\text { Confidence to Work w/ Others } \\
\text { Awareness of World Issues }\end{array}$ & $\begin{array}{l}\text { Weekly Full Club Meetings } \\
\text { All Conferences (four/year) } \\
\text { Pre-conference Delegation Meetings }\end{array}$ \\
\hline $\begin{array}{l}\text { Lisa Paulson, } \\
\text { Attorney \& } \\
\text { Former Club } \\
\text { Member }\end{array}$ & 29 & 2 & Overall Self-Confidence & $\begin{array}{l}\text { Most Conferences (three/year) } \\
\text { Pre-conference Delegation Meetings }\end{array}$ \\
\hline
\end{tabular}




\subsection{Intellectual Support}

To help students thrive in a competitive political environment and manage a complex organization, Elmwood's Model UN advisors provided five types of intellectual support: content knowledge about international issues, political strategies and skills, historical information about Elmwood's Model UN club, research strategies, and organizational management advice (see Table 5). In the process, advisors challenged students to complete tasks with progressively less adult support, serving as natural mentors who coached students through their own authentic decisions on various challenges, such as what ideas to include in a conference resolution or how to advertise for a club fundraiser. These intellectual supports enabled students to pursue political goals with greater independence and also to collaborate with adults and peers more effectively.

Table 5

Types of Support Provided by Elmwood Model UN Advisors

\begin{tabular}{lll}
\hline Intellectual Support & Administrative Support & Personal Support \\
\hline Content Knowledge & Delegating Complex Responsibilities & Encouragement \\
Political Strategies \& Skills & Holding Students Accountable & Availability \\
Institutional Memory & Sharing Logistical Tasks & \\
Research Strategies & & \\
Management Advice & & \\
\hline
\end{tabular}

\subsubsection{Content knowledge}

The veteran Model UN advisors in this study had substantial content knowledge about a wide array of international issues. Although they expected club members to conduct independent research about their assigned topics, advisors supported students' learning by explicitly sharing content knowledge with them, especially for newer members who were less skilled at finding information independently. Whereas Mr. Stein acknowledged that "there's a certain amount of sophistry that goes on at a Model UN conference," he firmly believed that "knowledge of the issues is a pre-requisite for making Model UN work" (Interview, December 11, 2009). 
In the days and weeks before conferences, students' country delegations arranged afterschool or lunchtime meetings with Mr. Kendall and Mr. Stein to share what they had learned independently, ask questions, and strengthen their content knowledge and arguments. For example, at one after-school meeting before an autumn conference, Mr. Kendall spent about a half-hour in the library with four freshmen who planned to represent Turkey on various committees. When Mr. Kendall arrived, the students already had a stack of relevant articles on the table, and he asked them to share what they had learned. Kendra and Carol began by explaining their understanding of Turkey's diverse population and unique geographic and cultural position between the Middle East and Europe. After listening to each student present what they had learned from their initial research, Mr. Kendall shared key facts about Turkey’s history, culture, and geography that he believed could strengthen their arguments (Field notes, October 30, 2009).

Mr. Stein took a similar approach, being careful not to engage in one-way communication. In a meeting just before the winter conference with the four-member Ghana delegation, which included two new Model UN members, he first discussed with students what they had learned from their research and then shared ideas about Ghana's sources of wealth and its relationships with other countries. Sarah, a senior, suggested to the group that Ghana could "serve as a bridge between Africa and the West," and Mr. Stein agreed, adding that China could also be a useful ally. He suggested documents for them to read and explained why they might be useful, leaving the work thereafter to the students themselves (Field notes, January 13, 2010). Thus, advisors structured their exchanges to foster student voice and as a mutual sharing of ideas among youth and adults. 
Advisors also had exchanges with club members about content during conferences. For example, at one conference in November, Kendra, representing Turkey on the Security Council, discussed a challenge with Mr. Kendall in the hallway during a committee break. Kendra expressed her disbelief about another student's position: “The U.S. delegate is saying that she can't negotiate with China [over the Israeli-Palestinian issue] because it could damage their economic relationship, but China wouldn’t jeopardize their economy over this issue.” In response, Mr. Kendall supported Kendra's point by sharing some statistics about the U.S.-China trade relationship, reinforced her inclination to build alliances with delegates representing Asian countries, and suggested options for persuading the U.S. delegate to support her resolution (Field notes, November 20, 2009). Short two- or three-minute conversations like this were a common means for students to learn important information at conferences. These enabled students to discuss their ongoing negotiations with an experienced adult who could consider their perspectives and help guide them to make well-informed decisions in their conference committees.

Although many student-advisor exchanges about content involved reciprocal sharing of information, there were times when students needed more direction. In such cases, advisors met with students one-on-one to clarify key points. At one such meeting during the November conference, Mr. Kendall met with Kendra after committee hearings to discuss the practical challenges of Afghan security, which her committee was planning to address. In the meeting, Kendra began by explaining her country's goal of keeping Afghanistan stable and the role of the opium trade in the region's stability. After expressing support for her understanding of Turkey's perspective, Mr. Kendall suggested that in committee hearings Kendra use unifying language, such as "maintaining safety and security" so that residents can "live in peace." Because her 
conference preparation had focused on learning about her own country rather than Afghanistan, he shared more background information about food production, the Taliban, the Karzai government, and the relationships among them (Field notes, November 19, 2009). Thus, whereas advisors occasionally resorted to direct instructional approaches, more typically they listened to students' conceptions of the issues, encouraged them to ask questions, and engaged in interactive, collaborative discussions of how to use that information to promote their countries' goals.

\subsubsection{Political strategies and skills}

In addition, advisors provided intellectual support to the Model UN students through their explanations, demonstrations, and exchanges aimed at fostering political strategies and skills. Foremost among these skills were public speaking, negotiation, and political writing. Although some Model UN students joined the group as skilled, confident public speakers, others recognized their shortcomings and requested guidance.

Students typically sought guidance after they had attended one or two conferences and had become interested in improving. Carol, for example, was a shy student who during two conferences rarely spoke in front of her committees (Field notes, November 19, 2009). She told me between committee hearings at her second conference, “I'm just afraid that I'm a bad speaker," (Memo, November 19, 2009). Before the next conference, she sought advice from Mr. Kendall after school one day, and he provided extensive advice:

I told her three things. First, "Don't try to be bombastic. You have a natural speaking voice that's quiet. Let that be your strength. Be slow; look at them; let your voice drop, and watch the room gravitate to your level of discussion." Then I told her not to read her speeches. One of her strengths is her expressiveness, her eyes; so she needs to just write an outline and then raise her face so they can see her and listen to her that way. The third 
one was to put two things at the beginning of every speech - a quick outline of the points she'll make... and acknowledgements of other delegates' points. If she does these things, she's gonna be a lot further along...Y You find the strength of a delegate and you let that work for them (Interview, January 13, 2010).

During conferences, Mr. Kendall visited different committees and offered specific speaking tips to students who sought his advice - often related to pacing, tone, and volume.

For new members, advisors regularly offered unsolicited advice, but for more experienced delegates, they encouraged more independence by responding only to their questions and concerns - assisting primarily to co-design strategies to gain support for resolutions or working papers. For example, when Mr. Kendall visited Sarah's committee hearing room at one conference, she shared with him her frustration about how her ideas were not being taken seriously. Her committee, a simulated World Health Organization, had been challenged to address a cholera outbreak in recently earthquake-ravaged Haiti, and while other delegates were developing a working paper that focused on the building of infrastructure, Sarah thought that a crisis situation required more immediate aid. Mr. Kendall suggested a strategy for expressing her view while working with those who had different priorities:

Think long-term and short-term. It's not or. Long-term and short-term. If you contradict [other delegates], they shut you out...You should say, "that's a good idea, but while we wait for the infrastructure, now we need to make sure people are okay" (Field notes, January 16, 2010).

Shortly thereafter, Sarah heeded this advice and successfully designed a working paper with students representing various countries. In this situation, Sarah clearly understood the content 
and possible directions for addressing the problem, but Mr. Kendall's strategy recommendation guided her on how to more productively cooperate with her peers.

Similarly, advisors offered advice on parliamentary procedure if this would help students to overcome challenging obstacles in passing their resolutions. At one autumn conference, Rebecca, an experienced senior member, had determined that her resolution would fail if brought to a vote, but she sought advice from Mr. Stein and learned about a rarely-used method for skirting objections to unpopular measures. After returning to her committee room, she raised her placard and made a "motion to divide the question," proposing to split the resolution into two parts, one of which would include the popular portions of the resolution, the other of which would include aspects which many delegates found objectionable. Shortly thereafter, her shorter resolution passed (Field notes, November 20, 2009).

Another skill with which advisors assisted students was political writing. Although students drafted position papers (see Appendix B) independently, advisors provided feedback upon request, helping them to use clear, diplomatic language. Before one conference, Ms. Paulson met with one country delegation at a coffee shop several times to help them edit their papers (Interview, March 20, 2010). During conferences, when students were writing working papers, they occasionally requested and secured advice from advisors about how to word a particular phrase to appeal to an array of potential allies (Field notes, January 16, 2010). Thus, Elmwood's advisors provided guidance on various political strategies and skills, but they expected more experienced members to operate more independently and to help new members in their committees. 


\subsubsection{Institutional memory}

The third type of intellectual support that advisors provided was helping to serve as the club's institutional memory. When students developed plans for the club, advisors mentored them by sharing background knowledge about how prior officers had addressed similar challenges.

For example, at an officers' meeting in late August, students began to discuss ways to network with outside organizations to generate financial support for conference scholarships. After students spent about fifteen minutes discussing possibilities, Mr. Kendall went to his computer and projected a Powerpoint slide that included numerous community organizations with whom previous iterations of the club had established relationships, such as the UN Association Student Alliance and local non-profit groups. Given this information, students discussed how to rebuild those connections instead of starting from scratch (Field notes, August 20, 2010).

There were many other times when the advisors drew on their experiences to help students consider important issues when they made plans. For example, at the club's August strategic planning meeting, when officers suggested kicking out members who did not attend meetings, Mr. Kendall told them that in the past such efforts had severely damaged membership numbers (Field notes, August 28, 2009). Then at one full club meeting, after students began to make a list of restaurants from whom to seek food donations for the conference they were hosting, Mr. Kendall and Mr. Stein added several local restaurants that had made donations in prior years (Field notes, September 21, 2009). Despite the natural turnover in the club's membership, advisors' institutional memory facilitated students' ability to make better-informed 
decisions about their organization and helped foster a collaborative leadership arrangement in which the perspectives of both adults and youth were useful and valued.

\subsubsection{Management advice}

Whereas students helped to establish the tone, direction, and priorities of the club (see section 4.3.1 below), advisors facilitated students' ability to achieve their goals by mentoring them on specific management strategies. For example, when two freshmen assumed responsibility for planning a fundraiser, several weeks before the event Mr. Kendall met with them after school to discuss the elements of the event, including publicity, decorations, and soliciting volunteers (Field notes, January 8, 2010). The students took notes at the meeting, talked to Mr. Kendall briefly at a later date to share their ideas and ask questions, and ran a successful fundraiser. Likewise, at a strategic planning meeting, when students discussed their interest in better preparing new members for conferences, they made a list of facts that they wanted new members to learn (e.g., international treaties). After ten minutes of this, Mr. Kendall encouraged them to consider issues beyond content, such as ways to strengthen members' skills. Then they began an interactive, student-dominated discussion about how to scaffold new members' participation in such practice debates, with senior Mary suggesting that meetings include "a point-counterpoint debate ... over something mundane like moving a juice box"

(Field notes, March 19, 2010). Mr. Kendall let the students finish this segment of the meeting on their own. Thus, advisors allowed students to set organizational goals, offered guidance on how to achieve them, and then let students re-take the reins.

\subsubsection{Research skills}

Finally, all three advisors provided important intellectual support on how to conduct research - for the purpose of either preparing for conferences or planning an event. Although 
advisors shared their own content knowledge directly (described above), they also provided tools and opportunities for students to gather information and formulate arguments independently. For example, during winter break, Mr. Kendall and Mr. Stein held meetings at a public library so that students could prepare for an upcoming conference. While students worked independently at tables - reading and discussing articles that they had found, the advisors walked around and suggested websites or books where students could find more information and references on their topics (Field notes, December 29-30, 2009). In the process, they encouraged students to consider their sources, advising one student, for example, to be wary of Wikipedia and referring another to Foreign Affairs (Field notes, December 30, 2009). As junior Randall said, "Mr. Stein helped me find the Law of the Sea and the articles that apply to my topic" (Interview, January 13, 2010), which introduced him to ideas that he raised during committee hearings (Field notes, January 16, 2010). Meanwhile, advisors and students accumulated potentially useful books, pamphlets, and other resources, and advisors asked students to organize them into a resource library.

Thus, youth and adults shared responsibility for certain intellectual tasks, such as identifying sources and strategizing during committee hearings, but advisors shifted certain duties to students, such as planning club meetings and organizing fundraisers. Although advisors were available to mentor students when students undertook various tasks (see section 4.4 below), the young people themselves decided how much time and effort to expend, what arguments to make, and the general direction of the club.

\subsection{Administrative Support}

To facilitate the club's activities, advisors provided administrative support while simultaneously scaffolding and shifting many administrative responsibilities to students. These supports included delegating complex responsibilities, holding students accountable, and sharing 
logistical tasks. Throughout the process, advisors positioned themselves as more experienced partners who worked reciprocally with students to facilitate youth-led decisions and community connections. When students lacked the requisite skills or commitment to complete certain tasks, advisors shifted back to serving as mentors to ensure that essential tasks were completed competently.

\subsubsection{Delegating complex responsibilities}

During their long tenure as advisors, Mr. Kendall and Mr. Stein had worked with students to develop a culture and a system in which students assumed numerous responsibilities, especially those that required complex managerial work. Mr. Kendall summarized his views on delegating responsibilities as follows:

I want the students to feel empowered to succeed, to try things, and also to fail and learn from that failure. ...When [students] say they want to do something, I ask, "Okay, how are you going to do it?" They know that they have to get it done. And if they don't follow through, they learn from that; or if they don't rally other people enough, they learn from that. Every aspect of this is educational - not just the international relations aspect (Interview, September 21, 2009).

Whereas advisors were regularly available to provide mentoring upon request, many activities, such as fundraisers and educational outreach programs, were largely student-led.

One key strategy for delegating responsibilities was through clearly defined student leadership positions. Nine officers elected each spring planned club meetings and completed important logistical tasks (see Table 6). For example, whereas the secretary-general was responsible for solidifying the club's annual goals, the president of assembly had to run large membership meetings with up to 40 members present. Several positions were typical of most 
clubs, but others were unusual, such as the External Affairs officer. Over the years, detailed descriptions of positions had been written into an officers' manual, so new and prospective officers could refer to them.

Table 6

Major Responsibilities of Officers for Elmwood Model UN*

\begin{tabular}{|l|l|}
\hline Office & Main Responsibilities \\
\hline Secretary-General & Plan meeting schedules; Develop vision for club; Monitor club's activities \\
\hline President of Assembly & Plan meeting agendas; Preside over meetings; Enforce Constitution \\
\hline USG of Finance** & Manage treasury, funds, and dues \\
\hline USG of External Affairs** & Form and maintain inter-school and community partnerships \\
\hline USG of Advocacy** & Propose and organize events to support authentic causes \\
\hline Rapporteur & Maintain research library, archives, and achievement \\
\hline USG of Internal Affairs** & Form and maintain relationships with other district schools \\
\hline SEMMUNA Ambassador & Organize and lead SEMMUNA (Southeast MI Model UN Association) Conference \\
\hline USG of Technology** & Update and maintain club web site; Check club email account \\
\hline
\end{tabular}

To minimize the effect of officer graduations, advisors encouraged younger students to run for these positions. During this study, the officer corps included two sophomores, two juniors, and five seniors. Elections for new officers occurred in February so that the outgoing officers could train their replacements. During the transition in March, several officers' meetings included both the new and outgoing officers, and a festive "New Officer Training" meeting at a local restaurant involved outgoing officers explicitly describing their responsibilities, strategies, and challenges to the newly elected leaders (Field notes, March, 2010).

Also, advisors invited non-officers to serve as leaders in various ways, such as conference country delegation captains, fundraiser organizers, or in other roles. As senior Sarah explained,

I think I learned the most this year in the club - more than in other years. I was head delegate for two conferences. It was my last chance to really step up. I had to prepare not 
only my stuff but helped other delegates prepare theirs. ... I proved to myself that I could be a leader rather than just take part in something (Interview, February 5, 2010). For experienced members who were not ready to be delegation captains, there were chances to assume more basic leadership roles. During each overnight conference, experienced members were paired with new members to serve as "buddies," whose job it was to ensure that new members returned safely to the hotel and impart to new members encouraging words or nominal gifts each conference day.

Furthermore, advisors offered all Model UN students the chance to participate in other leadership opportunities. For example, twice per year, Mr. Kendall hosted a strategic planning meeting, or "SPlaM." At these meetings, held in August and March, the secretary-general and Mr. Kendall created the agenda, which included discussion of the prior year's events and the upcoming year's goals, such as how to expand the club's membership. Students dominated the discourse at these meetings, with only occasional comments from Mr. Kendall (Field notes, August 28, 2009; March 19, 2010). Furthermore, advisors offered club members opportunities to plan and manage other events, such as planning and leading a half-day Model UN conference for middle school students (Field notes, December 12, 2009) and meeting with a local public official to shared their views on political issues (Field notes, May 24, 2010). For the latter, advisors did little beyond telling students about the opportunity and making introductions at the meeting. Overall, by delegating and offering students various responsibilities, advisors were able to facilitate students' leadership of club duties and support the development of relationships within their club, school, district, and community. 
Advising a Model United Nations Club 29

\subsubsection{Holding students accountable}

Advisors facilitated the club's operations and students' participation by helping to hold students accountable for responsibilities they had accepted. If an individual ran for office, got elected, and repeatedly failed to fulfill the duties specified in the officers' manual, the advisors often with the assistance of club members - would pressure the disengaged officer to assume responsibility. For example, in the fall of 2009, a senior officer in charge of checking the club email rarely did so and therefore risked missing messages that could have affected the whole group. Mr. Kendall and another officer explained to her the importance of this duty several times, and eventually she began to complete this task regularly. Also during this study, one officer was particularly inattentive to her duties - missing meetings and procrastinating on the year's largest fundraising effort. Mr. Kendall consulted the other officers about replacing her, and several of those officers tried to convince her to complete her duties - an effort which was ultimately successful. Such persuasive efforts were not always effective, however.

In the spring of 2009 (about six months before this study began), the club held early elections to replace a group of officers who had grown lax in their duties. According to Mr. Kendall, he takes a dramatic step like this every few years to set a high standard for officers: "I also need to send a message to all of my students that leadership means leadership. It doesn't mean holding an office for a resume or anything else" (Interview, August 28, 2009). Although advisors typically aimed to hold students accountable through leveraging their own and club members' persuasive efforts, they occasionally found it necessary to impose concrete consequences when officers were consistently inattentive to their responsibilities. If advisors sensed that the club was no longer a collaborative effort between youth and adults - and too 
much weight rested on advisors' shoulders, they sought to involve students more willing to work closely with them.

For the general group membership (i.e., non-officers), the advisors held students accountable by keeping track of students' progress and reminding them about their prior commitments. At each full club meeting, officers reserved a few minutes for advisors to speak at the end, most of which was spent making announcements that had also been made in previous weeks. Among the more common reminders were those concerning deadlines for conference position papers or conference fees; holding country delegation meetings; and getting involved in fundraisers (Field notes, October 26, 2009; November 2, 2009; January 4, 2010; January 11, 2010). Although reminding students of deadlines and duties was repetitive, Mr. Kendall and Mr. Stein viewed this as essential for facilitating students' participation in the club's activities.

\subsubsection{Sharing logistical tasks}

Despite advisors' efforts to delegate and scaffold responsibilities, some clerical tasks required their participation or close oversight. For example, before each conference, Mr. Kendall completed district forms to take students on a field trip, and he signed and approved the posters publicizing club events before students put them on the school's walls, as the school rules required (Field notes, August 28, 2009). In addition, advisors regularly shifted conference planning duties to students and tracked their progress after fulfilling the initial tasks of conference registration and assigning roles to students; advisors facilitated students' work on other clerical tasks, such as booking hotel rooms, arranging transportation, and collecting and depositing fees. For example, at several club meetings before the November conference, Mr. Kendall explained the challenge of bus transportation costs and asked students to recruit an “army" of potential parent drivers for conference transportation. Two students thereafter solicited 
and secured parent volunteers, making a list of contact information that officers or advisors could use in advance of conferences (Field notes, October, 2009). Thus, in addition to delegating complex responsibilities via student officer positions, advisors regularly shifted logistical tasks to students.

\subsection{Personal support}

In addition to guiding students intellectually and administratively, advisors provided personal support to Model UN club members. Although they received only nominal compensation for advising, they made themselves regularly available to serve as reliable, natural mentors, encouraging students' explorations of new ideas. In the process, they forged emotional connections and attachments with students, which helped to facilitate their work together.

\subsubsection{Encouragement}

Advisors consistently encouraged students' participation by suggesting that they become more involved in Model UN activities and by praising their efforts. At club meetings, when student officers led discussions with all the members about plans for upcoming conferences and fundraisers, Mr. Kendall and Mr. Stein customarily added their endorsements and enthusiastically encouraged them to participate. Then at conferences, they spent most of their time sitting in the back of committee rooms, observing students' interactions, and pulling aside students individually to encourage them to make a speech, develop a working paper, or persist amidst a challenging debate. For example, at the large fall conference, Mr. Kendall encouraged a delegate representing Afghanistan to officially propose the amendment that he was developing: "The room is dead right now. People are waiting for something interesting to happen. This is your chance to put this thing forward and get it passed" (Field notes, November 20, 2009). 
Often students had difficulties in committees, facing stiff opposition or feeling nervous. When students expressed these concerns to advisors, they usually offered suggestions and encouraging words. At the winter conference, Mr. Kendall spoke with freshman Kendra, then representing Iraq, to urge her to get involved. She said that she was nervous to talk in front of so many experienced upperclassmen. Then Mr. Kendall responded by referring to an Elmwood senior in her committee:

I want you to be like [Bakari] by your sophomore year. I see it. . . . When I see a strong delegate and I see someone as bright as you are, I know it. I think you can be a delegate who can take charge of a committee, but it's going to happen [only] if you practice.... Even though they've marginalized you, get yourself involved. Let them know that [the delegate from] Iraq is a thinker. . . . I'm so excited to see this placard go up (Field notes, January 15, 2010).

Although Kendra initially resisted, Mr. Kendall reassured her, and shortly thereafter she asked a question of the speaker and began to meet with other delegates to develop a resolution.

In addition to offering real-time encouragement during conference committee meetings, after each day at a conference, all three advisors met with the full Elmwood team to share flattering stories of students' conference activities and encourage them to continue their efforts. At one such gathering, Mr. Stein explained senior Rebecca's complex but successful strategy to pass a resolution, ending on an enthusiastic note: "Pow! Passed it. Done. Slam dunk! Nice job." Students' cheers then erupted. Then Ms. Paulson's comments included complimentary words for students in the General Assembly, and she encouraged them to strategize more carefully the following day to network with other countries' delegations to win votes (Field notes, November 
19, 2009). Such positive collective moments not only encouraged students' deeper involvement in debates but also helped to foster positive relationships and connections among the group.

\subsubsection{Availability}

Advisors committed substantial time to supporting the club's formal activities, and they made themselves widely available to students for conference preparation, coaching, and informal exchanges. Mr. Kendall and Mr. Stein regularly invited students to plan meetings with them for conference preparation, giving students the option of coming to their classrooms during lunch or after school. Likewise, Ms. Paulson met with students during evenings several times before each conference. As mentioned above, during two days of winter break, Mr. Kendall and Mr. Stein reserved a room at the local public library for six hours and invited Model UN students to come there to conduct research, discuss debate strategies, and enjoy each other's company. At the conferences, all three advisors circulated to different committee rooms both to observe students and to answer their questions. At conference hotels, Mr. Kendall and Mr. Stein shared a room that served as a headquarters, where after the day's committee sessions had ended, students could visit to receive advice or interact casually with advisors and one another (e.g., Field notes, November 19, 2009; January 15, 2010).

Mr. Kendall also made himself available to help students with other activities beyond normal meeting or conference times. After Friday officers' meetings, students regularly stayed in his classroom to discuss issues in greater detail. After one meeting in the fall, two students spent about a half-hour probing Mr. Kendall about strategies for soliciting food donations for the conference hosted at their school (Field notes, October 23, 2009). Later in the year, Mr. Kendall and an experienced club officer, Sarah, spent about twenty minutes after school with another student, Vivian, interested in helping with conference logistics, such as how club money is spent 
(Field notes, January 22, 2010). Then over the next few weeks Vivian conducted those activities independently, turning to Mr. Kendall and Sarah when she had questions.

If students wanted to discuss issues unrelated to Model UN, Mr. Kendall would regularly make time for them. One day after an autumn club meeting, two students began a discussion with him about the value of education, which veered into questions about life's purpose and other philosophical issues (Field notes, September 14, 2009). This continued even after students graduated, as some Model UN alumni maintained contact with the advisors - visiting their classrooms, sending emails or letters, or meeting them at conferences. Through their availability and encouragement, Mr. Kendall and the other advisors served as mentors to students by providing personal support and building strong attachments.

\section{Discussion}

This paper illustrates how Model UN advisors can facilitate the development of an extracurricular club in which students not only become deeply involved but also assume responsibility for leading and managing the group. By documenting how advisors worked collaboratively with youth and scaffolded their involvement in an emotionally supportive environment, I have provided insights that can be useful for adult advisors of various youth leadership and other extracurricular activities. Furthermore, this research makes a valuable contribution to the scholarship on youth-adult partnerships by examining the nuances involved in collaborations that have primarily educational goals. Below, I provide more details on the implications of this work.

\subsection{Scholarly Contribution}

Model UN has flourished for nearly seven decades and has millions of alumni around the world, but little prior research has examined how advisors facilitate students' participation or 
important civic outcomes. This study begins to fill this gap by documenting and analyzing the ways that one club functioned as a strategically facilitated youth-adult partnership involving developmental relationships. Within this context, advisors provided intellectual, administrative, and personal support, attending to students' need for guidance (Rogoff et al., 2001) while progressively shifting responsibilities to youth as they developed the necessary competence, commitment, and connections to work more independently and collaboratively. These findings are useful for scholars interested in how extracurricular clubs or other groups can foster youth leadership.

Whereas prior research specifies how organizations with both youth and adults can engage in shared work (Kirshner, 2008; Zeldin et al., 2013) to foster an appropriate balance of power (Li \& Julian, 2012), this study specifies categories of work involved in such groups and illustrates that relationships and roles may shift across these categories. For example, advisors and students worked collaboratively to shape the direction of the club in strategic planning meetings and officers' meetings, but at conferences, some of these same students (e.g., senior officer Rebecca) sought direct mentoring from the advisors (e.g., on parliamentary procedure strategies). Likewise, although adult advisors could reasonably scaffold and delegate certain administrative or intellectual tasks, such as booking conference hotel rooms or identifying useful information about a country, other related tasks often required more guidance from these adults, depending on students' needs. Furthermore, the personal support that advisors provided appeared to bolster students' interest in spending time with advisors and seeking their guidance - and may have been crucial for their ongoing participation. Thus, this study illustrates the dynamic and fluid nature of the roles that students and adults may play in their ongoing work together. 


\subsection{Practical Implications}

This study has several important implications for advisors of extracurricular clubs and teachers. First, this study adds to the existing research that suggests that sharing knowledge is necessary but not sufficient for student learning, skill development, or attitudinal changes (Anderson \& Krathwohl, 2001; Dewey, 1938; Donovan \& Bransford, 2005; Kolmuss \& Agyeman, 2002; Rodgers, 2002). Although advisors' structured provision of content knowledge helped to stimulate or strengthen students' preparation for conference committee discussions and event planning, other types of intellectual, administrative, and personal support were also important for supporting students' successful involvement. For example, helping students learn how to lead a meeting and negotiate a compromise through experience and with supportive feedback enabled students to work more independently and practice skills that could be useful in various domains, civic and otherwise. Meanwhile, this process shifted responsibility and decision-making away from advisors and towards students, thus lightening the management burden from the adults and providing students with leadership opportunities. Educators and advisors of student groups may find that shifting to students more responsibility for complex tasks, such as studying content, practicing skills, and making decisions, can ultimately strengthen students' self-efficacy and learning in certain spheres.

Nonetheless, adjusting the culture of how students engage in club or classroom activities may be challenging, especially if they have limited relevant experiences, knowledge, or motivation. This study provides insights about how different types of intellectual support facilitated students' Model UN participation and may be useful to educators undertaking such adjustments (see Table 5). For example, to help students prepare for conferences, instead of simply sharing information with students, advisors guided students to information resources and 
helped them learn to find their own resources - thus enabling them to become more independent learners. Moreover, the structure of Model UN, which invites young people to design solutions to real-world challenges, provides a model that educators, especially those in social studies fields, should consider when they select or create curricula. Such problem-based curricula can facilitate students' pursuit of knowledge and development of skills as they engage with others on authentic tasks (e.g., Hmelo-Silver, 2004). Students often become more motivated to learn in such programs (e.g., Krajcik \& Blumenfeld, 2006), and this study illustrates that educators and advisors may still have a vital role to play in directly providing unique expertise and encouragement.

Another practical implication of this study is that there are numerous ways for advisors to progressively share and shift intellectual, administrative, and even personal supports to students. Although it may be necessary for adults to conduct specific aspects of an endeavor, such as signing forms or establishing initial routines, providing students opportunities to complete tasks and make consequential decisions related to building an organization or addressing a complex problem can help prepare them for the real work of civic participation. In Elmwood High School's Model UN club, the officer corps undertook numerous administrative tasks and helped to train new officers; country delegation leaders ensured that their peers were prepared for conferences; and other students had the chance to plan fundraisers and other large events. Whereas advisors provided support, they also fostered students' sense of empowerment (see Levy, 2011a for more on this), especially as students gained greater club experience. This sense of empowerment can increase not only students' investment and participation in their current activities but also their interest in becoming involved in broader endeavors, such as civic and political affairs (Levy, 2013). 
Given the specific context of Elmwood's Model UN program, the implications of this study may not be generalizable to all such groups. This study took place in a district and organization with mostly white, middle-class students, many of whom had flexibility after school to engage in various activities. Some students do not have this flexibility. More heterogeneous student groups, however, might also have provided a greater breadth of perspectives in political and organizational discussions. Also unique to Elmwood's club was the fact that Mr. Kendall and Mr. Stein had spent over a decade working together at Elmwood High, which contributed to the mutual rapport and community connections that facilitated their ability to provide certain supports. Nonetheless, the findings of this analysis could be useful to many educators interested in fostering students' leadership development and civic engagement. The supports and activities described in this paper may not be precisely replicated in other settings, but the categories and framework may help educators and researchers consider how youth and adults can dynamically and productively share, shift, support, and split responsibilities in such programs.

\subsection{Future Research}

Educational leaders and scholars have long emphasized the importance of preparing young people for their roles as citizens (Hertzberg, 1981; Westheimer \& Kahne, 2004; Knight Abowitz \& Harnish, 2006), and it is important to continue examining how programs during and beyond the school day can successfully do this. Model UN and several other programs, such as the Legislative Semester, are structured to include political discussions and various activities known to foster political interest and efficacy (Hahn, 1999; Ganzler, 2010; Hess \& McAvoy, 2015; Kahne, Crow, \& Lee, 2010; McAvoy \& Hess, 2013). Studying their implementation in a variety of contexts could help educators better understand strategies for managing such complex programs. Given the civic empowerment gap between those from higher and lower 
socioeconomic backgrounds (Levinson, 2012), it may be especially useful for researchers to explore how educators support leadership development among youth from different ethnic, linguistic, or socioeconomic backgrounds. With the recent expansion of Model UN to urban classrooms around the world (UN Association of the USA, 2009), there may be many opportunities to conduct such research.

In these explorations, it would be useful for scholars to explore both how educators manage such programs and also the range of student outcomes. Building on this study, for example, researchers could further examine how educators foster young people's independent or shared exploration of issues and content. Whereas the present analysis identified several categories in which advisors supported and scaffolded students' intellectual work, future research may pinpoint nuances within these or similar categories, such as effective strategies for fostering critical media literacy for online news sources. Furthermore, whereas the program described in this paper was found to foster students' political interest and efficacy, programs that engage students in action civics projects, such as Project Citizen and Mikva Challenge (Kornfeld, Bass, \& Levy, 2016), may support different dimensions of civic engagement (Gould, Jamieson, Levine, McConnell, \& Smith, 2011). Researchers could examine how educators guide these experiences in ways that provide youth with opportunities to develop student voice (Mitra \& Serriere, 2012), civic skills (Brady, Verba, \& Schlozman, 1995), psychological involvement in political issues (Cohen, Vigoda, \& Samorly, 2001), or action competence (Jensen \& Schnack, 1997).

\section{Conclusion}

This study is a first step towards understanding how adult advisors support students' participation in and civic development through Model UN clubs, and it provides useful analyses and implications about the practices, challenges, and complexity of facilitating these and other 
complex youth programs. Given the growth of Model UN and other civic learning programs around the world, it is important to continue studying these groups, especially their implementation, structure, and outcomes in diverse settings. Such research could help educators, policymakers, and others who wish to foster youth civic and political engagement. 


\section{References}

Almond, G., \& Verba, S. (1963). The civic culture. Princeton, NJ: Princeton University. Becker, R. (2005). Political efficacy and voter turnout in East and West Germany. Swiss Political Science Review, 11(1), 57-86.

Anderson, L. W., \& Krothwahl, D. R. (2001). A Taxonomy for Learning, Teaching, and Assessing. New York: Longman.

Benson, P. L., Scales, P. C., Hamilton, S. F., \& Sesma Jr., A. (2006). Positive youth development: Theory, research, and applications. In W. Damon \& R. M. Lerner (Eds.), Handbook of child psychology, Vol. 1. Theoretical models of human development (6th ed., pp. 894-941). Hoboken, NJ: Wiley.

Bernstein, J. L. (2008). Cultivating civic competence: Simulations and skill-building in an introductory government class. Journal of Political Science Education, 4(1).

Boocock, S. S. (1968). An experimental study of the learning effects of two games with simulated environments. In S. Boocock \& E. Schild (Eds.), Simulation games in learning (pp. 107-133). Beverly Hills, CA: Sage.

Bouza, L. (2014). Addressing youth absenteeism in European elections. Aisbl: International Institute for Democracy and Electoral Assistance.

Brady, H., Verba, S., \& Schlozman, K. L. (1995). Beyond SES: A resource model of political participation. American Political Science Review, 89(2), 271-94.

Campbell, A., Gurin, G., \& Miller, W. (1954). The voter decides. Evanston: Row, Peterson. Center for Information and Research on Civic Learning and Engagement (2013). The youth vote in 2012. Circle Fact Sheet. Retrieved from http://www.civicyouth.org/wpcontent/uploads/2013/05/CIRCLE_2013FS_outhVoting2012FINAL.pdf 
Cohen, A., Vigoda, E., \& Samorly, A. (2001). Analysis of the mediating effect of personal psychological variables on the relationship between socioeconomic status and political participation: A structural equations framework. Political Psychology, 22, 727-757.

Craig, S. C., Niemi, R. G., \& Silver, G. E. (1990). Political efficacy and trust: A report on the NES pilot study items. Political Behavior, 12(3), 289-314.

Dewey, J. (1915). The School and Society. Chicago, IL: University of Chicago Press.

Dewey, J. (1938). Experience and Education. New York: Collier Books, Macmillan.

Dressner, M. M. (1990). Changing energy end-use patterns as a means of reducing global warming trends. The Journal of Environmental Education, 21(2), 41-46.

Donovan, M.S., \& Bransford, J. D. (2005). How Students Learn: History, Mathematics, and Science in the Classroom. Washington, DC: National Academies Press.

Durlak, J. A., Weissberg, R. P. \& Pachan, M. (2010). A meta-analysis of after-school programs that seek to promote personal and social skills in children and adolescents. American Journal of Community Psychology 45 (3-4), 294-309.

Dworkin, J., Larson, R., \& Hansen, D. (2003). Adolescents' accounts of growth experiences in youth activities. Journal of Youth and Adolescence, 32, 17-26.

Eccles, J. S. (2005). Subjective task value and the Eccles et al. model of achievement-related choices. In Elliot, A. J. \& Dweck, C. S. (Eds.). Handbook of Competence and Motivation. New York: Guilford Press.

Finkel, S. E. (1985). Reciprocal effects of participation and political efficacy: A panel analysis. American Journal of Political Science, 29(4), 891-913.

Foreman, P. B. (1948). The theory of case studies. Social forces, 26(4), 408-419. 
Franklin, M. N. (2004). Voter turnout and the dynamics of electoral competition in established democracies since 1945. Cambridge, UK: Cambridge University Press.

Ganzler, L. M. (2010). Simulated citizen: How students experience a semester length legislative simulation. (Unpublished doctoral dissertation.) University of Wisconsin-Madison.

Gimpel, J., Lay, J. C., \& Schuknecht, J. E. (2003). Cultivating Democracy: Civic environments and political socialization in America. The Brookings Institution, Washington, DC.

Glaser, B., \& Strauss, A. (1967). Discovery of grounded theory. Chicago: Aldine.

Gould, J., Jamieson, K. H., Levine, P., McConnell, T., \& Smith, D. (2011). Guardian of Democracy: The Civic Mission of Schools. Annenberg Institute for Civics, University of Pennsylvania, Available online at http://www.ncoc.net/guardianofdemocracy.

Guyton, E. (1988). Critical thinking and political participation: Development and assessment of a causal model. Theory and Research in Social Education, 16(1), 23-49.

Hahn, C. L. (1999). Citizenship education: An empirical study of policy, practices, and outcomes. Oxford Review of Education, 25(1-2), 231-250.

Hamilton, S. F., \& Hamilton, M. (2009). The transition to adulthood: Challenges of poverty and cultural lag. In R. M. Lerner \& L. Steinberg (Eds.), Handbook of adolescent psychology (Vol. 3, pp. 492-526). New York: Wiley.

Hazleton, W. A., \& Jacob, J. E. (1983). Simulating international dipolomacy: The national Model United Nations experience. Teaching Political Science 10(2), 89-98.

Hertzberg, H.W. (1981). Social studies reform, 1880-1980. Boulder, CO: Social Studies Education Consortium.

Hess, D. (2009). Controversy in the classroom: The democratic power of discussion. New York: 
Routledge.

Hess, D. \& McAvoy, P. (2015). The political classroom. New York: Routledge.

Ikeda, K., Kobayashi, T., \& Hoshimoto, M. (2008). Does political participation make a difference? The relationship between political choice, civic engagement and political efficacy. Electoral Studies, 27(1), 77-88.

Jensen, B. B., \& Schnack, K. (1997). The action competence approach in environmental education. Environmental Education Research 3(2), 163-78.

Kahne, J., Crow, D., \& Lee, N. (2010). Discussion-based and experiential high school curricula: Their differential impact on civic and political outcomes. Unpublished manuscript.

Kirshner, B. (2008). Guided participation in three youth activism organizations: Facilitations, apprenticeship, and joint work. Journal of the Learning Sciences 17(1), 60-101.

Kollmuss, A. \& Agyeman, J. (2002) Mind the gap: Why do people act environmentally and what are the barriers to pro-environmental behavior? Environmental Education Research, 8(3), $239-260$.

Knight Abowitz, K. \& Harnish, J. (2006). Contemporary discourses of citizenship. Review of Educational Research, 76(4), 653-90.

Koch, J. W. (1993). Assessments of group influence, subjective political competence, and interest group membership. Political Behavior, 15(4), 309-325.

Kornfeld, E., Bass, J., \& Levy, B. L. M. (2016). Fostering diverse youth voices: Philosophy, strategies, and outcomes of the democracy in action program. In C. Wright-Maley, \& T. Davis (Eds.), Teaching for democracy in an age of economic disparity. New York: Routledge. 
Krajcik, J. S. \& Blumenfeld, P. C. (2006). Project-based learning. In Sawyer, R. K. (Ed.). The Cambridge Handbook of the Learning Sciences. Cambridge, UK: Cambridge University.

Leighly, J. E. \& Vedlitz, A. (1999). Race, ethnicity, and political participation:

Competing models and contrasting explanations. Journal of politics, 61(4), 1092-1114.

Levinson, M. (2012). No Citizen Left Behind. Cambridge, MA: Harvard.

Levy, B. L. M. (2011a). 'I could make a difference': Research and theory on fostering adolescents' political efficacy and engagement. Unpublished doctoral dissertation, University of Michigan, Ann Arbor.

Levy, B. L. M. (2011b). Fostering cautious political efficacy through civic advocacy projects: A mixed methods case study of an innovative high school class. Theory \& Research in Social Education, 39(2), 238-277.

Levy, B. L. M. (2013). An empirical exploration of factors related to adolescents' political efficacy. Educational Psychology, 33(3), 357-390.

Li, J. \& Julian, M. M. (2012). Developmental relationships as the active ingredient: A unifying working hypothesis of "what works" across intervention settings. American Journal of Orthopsychiatry 82(2), 157-66.

Louis, W. R., Taylor, D. M., \& Neil, T. (2004). Cost-benefit analyses for your group and yourself: The rationality of decision-making in conflict. International Journal of Conflict Management, 15(2), 110-143.

Lupia, A., \& Philpot, T. S. (2005). Views from inside the Net: how websites affect young adults' political interest. Journal of Politics, 67(4), 1122-1142.

McAvoy, P., \& Hess, D. (2013). Classroom deliberation in an era of political polarization. Curriculum Inquiry, 43(1), 14-47. 
Merriam, S. B. (1988). Case study research in education. San Francisco, CA: Jossey- Bass.

Mitra, D. (2004). The significance of students: Can increasing "student voice" in schools lead to gains in youth development? Teachers College Record, 106(4), 651-688.

Mitra, D., \& Serriere, S. (2012). Student voice in elementary-school reform: Examining youth development in fifth graders. American Educational Research Journal, 49, 743-774.

Morrell, M. E. (2005). Deliberation, democratic decision-making and internal political efficacy. Political Behavior, 27(1), 49-69.

National Model United Nations (2016). About Us - Positive Impact, Quality Experience. Retrieved from http://www.nmun.org/ncca.html on 9 Sept 2015

Parker, W. C., \& Hess, D. E. (2001). Teaching with and for discussion. Teaching and Teacher Education, 17, 273-89.

Patterson, J. R. (1996). Model United Nations simulations: An inquiry into active learning, roleplaying, and role identification as they impact participants' sense of political efficacy. Unpublished doctoral dissertation, Kent State University, Kent, Ohio.

Putnam, R. (2000). Bowling Alone. New York: Simon \& Schuster.

Rodgers, C. (2002). Defining reflection: Another look at John Dewey and reflective thinking. Teachers College Press, 104(4), 842-66.

Rogoff, B., Bartlett, L., \& Turkanis, C. G. (2001). Lessons about learning as a community. In B. Rogoff, C. G. Turkanis, \& L. Bartlett (Eds.), Learning together: Children and adults in a school community (pp. 3-17). Oxford, UK: Oxford University.

Rogoff, B. (2003). The cultural nature of human development. Oxford, UK: Oxford University. Sewell, A., St. George, A., \& Cullen, J. (2013). The distinctive features of joint participation in a community of learners. Teaching and Teacher Education 31(x), 46-55. 
Siegel, M. E. (1977). Citizenship education in five Massachusetts high schools. Theory and Research in Social Education, 5(2), 25-76.

Smith, C., Peck, S. C., Denault, A., Blazevski, J., \& Akiva, T. (2010). Quality at the point of service: Profiles of practice in after-school settings. American Journal of Community Psychology 45(3-4), 358-69.

Stake, R. (1995). The art of case study research. Thousand Oaks, CA: Sage.

Steinberger, P. J. (1981). Social context and political efficacy. Sociology and Social Research, 65(2), 129-141.

Strauss, A., \& Corbin, J. (1999). Basics of qualitative research: Techniques and procedures for developing grounded theory. London, England: Sage.

Turner, C. (1997). Model United Nations simulations as secondary learning and teaching strategies. Unpublished doctoral dissertation, Auburn University, Auburn, Alabama.

United Nations Association of the United States of America (2013). Model UN: Bridging the education gap and creating global citizens. Retrieved from http://unausa.org/globalclassrooms-model-un on 9 Sept 2015.

Vogel, R. (1973). The effect of a simulation game on the attitude of political efficacy. Simulation and Games, 4, 71-79.

Watkins, C. (2005). Classrooms as learning communities: What's in it for schools? London: Routledge.

Westheimer, J. \& Kahne, J. (2004). What kind of citizen? American Educational Research Journal, 41(2), 237-269.

Williams, J. (2009). Global classrooms marks a decade of Model UN. UNA-USA World Bulletin. Retrieved October 10, 2009, from http://www.unausa.org/Page.aspx?pid=1284. 
Wolfe, T. (2013, February 12). Telephone interview with Troy Wolfe, Director of Education Programs for the United Nations Association.

Wong, N. T., Zimmerman, M. A., \& Parker, E. A. (2010). A typology of youth participation and empowerment for child and adolescent health promotion. American Journal of Community Psychology, 46, 100-114.

Yohalem, N. \& Wilson-Ahlstrom, A. (2010). Inside the black box: Assessing and improving quality in youth programs. American Journal of Community Psychology 45 (3-4), 350-57.

Zeldin, S., Christens, B. D., \& Powers, J. L. (2013). The psychology and practice of youth-adult partnership: Bridging generations for youth development and community change. American Journal of Community Psychology 51(3-4), 385-397. 


\section{Appendix A}

\section{Selected Model UN Conference Resolution}

Resolution: \#601

Submitted to: World Health Organization

Topic: Maternal Mortality

Sponsored by: USA, Kuwait, Nigeria, Pakistan, Croatia, Australia, Sudan

Signatories: Iran, France, Cuba, Japan, Venezuela, Algeria

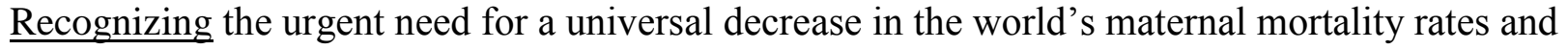
the need for a stable UN agenda to set guidelines and put a plan into action, and

Deeply troubled by the fact that the aforementioned rates are not in line with existing medical advancements, and

Alarmed by the challenge that women face to receive legal, social, political, and economic equality in society, and

Fully convinced that it is in the best interest of the global economy to rely on previously established organizations in order to solve this problem efficiently, and

Cognizant of the importance of community-based education regarding nutrition and reproductive health, and

Taking into account the mission of the MDG5 in lowering maternal mortality rates by 2015:

1. Endorses the reallocation of resources and funds of NGOs that, after having familiarized themselves with the needs of each specific nation, will work concurrently with ECOSOC in order to more effectively remedy the situation;

2. Encourages said pre-existing NGOs to continue their efforts in community-based education in terms of:

a. Pre and post-natal care,

b. Prenatal nutrition,

c. Proper sanitary procedures,

d. Types and use of contraceptives,

e. All scopes of culturally sensitive family planning;

3. Further encourages pre-existing NGOs to continue their medical treatment of and resource distribution to women at risk of pregnancy complications within developing nations, including, but not limited to:

a. Oxytocin (for injection after childbirth to lower blood pressure and prevent excessive bleeding),

b. Magnesium sulfate (to treat hypertensive reactions such as eclampsia), 
c. Partographs (to discern both maternal and fetal conditions during progress of labor, and, if necessary, to save the mother from a dangerous, obstructed labor and indicate need for Caesarian section),

d. Sterile equipment (to prevent sepsis and other infections),

4. Further endorses the training of doctors, nurses, and midwives by organizations such as IMPAC;

5. Recommends NGO aid reports to be given every three years in order to more accurately monitor progress toward achieving MDG5;

6. Recognizes the right of each nation to either reject or accept the use of NGOs or implement suggested practices as it sees fit. 
Advising a Model United Nations Club 51

\title{
Appendix B
}

\section{Selected Position Paper for Model UN Conference}

\author{
Author: Evelyn
}

SUBMITTED TO: Special Political Committee

FROM: Islamic Republic of Afghanistan

SUBJECT: Question of Palestine

The legal status of Palestine has caused much strife in the Middle East and much conflict abroad over the past 60 years. To the nation of Afghanistan, a fellow Islamic entity, the answer is obvious; the region of Palestine should be recognized as a sovereign nation by members of the United Nations, particularly the states of Israel and the United States.

The territory of Palestine, under the control of the Palestine Liberation Organization (PLO), is prepared to become an official sovereign state thanks to the structure of the PLO and its overwhelming support from Palestinians. The PLO functions as a government, maintaining a parliament (Palestine National Council), a standing army (Palestine Liberation Army), and a treasury department (Palestine National Fund).

Despite this level of organization lacked even by some current members of the United Nations, Palestine is continuously barred from gaining nation status by the undermining of Palestinian dignity by the state of Israel. Israel continues to expand their borders into Palestinian territory and prevent foreign aid from entering the West Bank and Gaza Strip.

The fundamental human rights of Palestinian citizens must be protected. The most effective way to ensure this is to legitimize borders between Israel and Palestine. An assurance of legitimacy would stabilize the region and lead to the creation of diplomatic relations between Middle Eastern nations involved in this conflict.

Palestine not only deserves recognition as a sovereign nation, but has proved itself worthy of said recognition countless times.

Although the answer to the Palestinian question is an easy one, the Islamic Republic of Afghanistan understands the process of achieving such a solution will not be so quick. However, the status of the Palestinian territories should ultimately be the decision of Palestine, under the direction of the Palestine Liberation Organization. 


\section{Appendix C}

\section{Vignette of a Conference Committee}

Below is a brief vignette of one segment of the fifty-person "Special Political Committee" during a conference held at a university in January, 2010. This portrait illustrates activities for which Model UN students prepare, such as giving speeches, using parliamentary procedures, discussing political issues, and accurately representing one's assigned country. The topic is the "One China" policy, which argues that Taiwan is part of China and that foreign governments should recognize this in their diplomatic, economic, and military actions. The meeting depicted below began with speeches by delegates who had signed up for the speakers' list, each of whom had a one-minute time limit. Most of the fifty delegates sat in their seats facing the speakers' podium while others moved about, engaging in side conversations about the speakers, proposed resolutions, or other matters. The chair, a college student who belonged to the university-based student-run organization leading the conference, sat at the front of the room, gavel in hand. The quotations below are paraphrased from participants' actual words.

Mexico Delegate: [At podium] The United Mexican States are worried about the "One China" policy because it rejects a free people's right to determine their own destiny. We think the Republic of China [Taiwan] deserves the right to a democratic government and should manage relations with other nations as it wants to. Um, I yield my time to the chair. [Leaves podium and sits down.]

Chair: Thank you, delegate. The chair now yields the floor to the delegate from the People's Republic of China. Delegate, you have one minute.

People's Republic of China (PRC) Delegate: [Leaves seat and walks to podium to begin speech] Taiwan is currently being led by a group of rebels who claim that they are an independent nation when this is not true. Taiwan is historically part of our country, and if nations around the world condemn us and our One China policy, we might just break our ties with the United Nations. We

don't want to be part of an organization that puts us down all the time. The countries of the world need us more than we need them. I yield my time to questions.

Chair: Thank you, delegate from the PRC. Are there any questions for the delegate from the PRC? [Several delegates seated in the room raise their placards, which include their countries' names.] Venezuela, you have thirty seconds for your question.

Venezuela Delegate: [Stands by his seat, speaking tentatively while reading her question from a notebook.] Uh, thanks to the chair. Venezuela hears what the PRC is saying but is concerned if your country withdrew from the UN. If you did, would the PRC still buy oil from Venezuela?

PRC Delegate: Thank you for the question. If this committee of the UN condemns China for merely asserting its historic rights, we will consider that a serious offense and will reshape many aspects of our foreign policy, including trade. The positions that each country takes on the issue could influence their ability to trade with us. 
Chair: Thank you, delegate.

[After several more speeches over the course of fifteen minutes, one delegate introduces a working paper for consideration.]

USA Delegate: [At podium] I am introducing Working Paper 1A, which is co-authored by the U.S., India, Saudi Arabia, France, and Ghana and which is signed by eight other countries. This working paper says that this committee supports bilateral talks between China and the U.S. to resolve some of their differences on this issue before the UN weighs in. You can all read it when you get a copy. These are the two main countries concerned about the One China policy, and this committee has other important issues to address, like the water crisis in the Middle East. We're not likely to solve the One China issue unless China and the US are happy.

Chair: Thank you, delegate. Could the secretary please pass out copies of the working paper? [The secretary does so. The delegate from Burkina Faso raises her placard.] The chair recognizes the delegate from Burkina Faso.

Burkina Faso Delegate: [Standing at her seat.] Motion for a five-minute moderated caucus with 30 -second speaking time to talk about the working paper.

[After the motion is seconded, committee members vote in favor of a moderated caucus by a large margin. About ten delegates then give short speeches about the working paper, which eventually becomes a resolution and is passed before the committee shifts to the topic of water rights in the Middle East.] 
Advising a Model United Nations Club 54

\section{Appendix D}

\section{Selected "Crisis" Situations at Model UN Conferences}

In the World Health Organization committee:

There is now an outbreak of cholera in Haiti. Although there has always been cholera in Haiti, the lack of clean, moving water is creating an escalated situation. Current reports of 100 confirmed cases of cholera from hospitals, but since many people cannot get to medical attention, the estimated number from our doctors is about 1,500. However, this number is triple what we found yesterday.

Usual treatment of cholera is oral hydration, but giver the lack of water in the country, external aid is needed. Oral hydration is drinking water along with salts and sugars. Each moderately dehydrated adult needs 4 liters of water in the first 4 hours. Severely dehydrated adults need intravenous fluids. Thus, our best estimates give a need of 10,000 liters of water for today, but at least 100,000 liters over the course of the next week in order to curb future infection rates.

Also, 5,000 doses of doxycycline (antibiotic) are needed; along with 1,000 doses of trimethoprim-sulfamethoxazole (antibiotic) for children, and 700 doses of furazolidone (antibiotic) for pregnant women.

In the Disarmament and Security Committee:

Manhattan, NY - At 9:52 AM EST, the UN delegate from Laos in the DISEC committee was abducted by what is now confirmed as a radical group of Tibetan separatists, the Three Dragons. The Three Dragons released a hostage video showing the delegate demanding small arms and 70 million dollars from Laos and other Association of Southeast Asian Nations (ASEAN) governments in exchange for the hostage. Laos has expressed interest in negotiating for the hostage's release. Other ASEAN nations have publicly stated their official policies that they will not negotiate with terrorists. Further journalistic investigation reveals that many of the ASEAN governments are secretly negotiating for the release of the UN delegate. The ten ASEAN nations are Indonesia, Malaysia, Philippenes, Singapore, Thailand, Brunei, Myanmar, Cambodia, Laos, and Vietnam. Negotiations could be crippling toward any rescue missions and would violate international laws regarding arms trade. 